\title{
Fungal biotransformation of limonene and pinene as a biotechnological approach for production of aroma compounds
}

\author{
Elison de Souza Sevalho ( $\square$ elisonsevalho@hotmail.com ) \\ University of Amazonas State: Universidade do Estado do Amazonas https://orcid.org/0000-0003-4754-3777 \\ Bruno Nicolau Paulino \\ Federal University of Amazonas: Universidade Federal do Amazonas \\ Antonia Queiroz Lima de Souza \\ Federal University of Amazonas: Universidade Federal do Amazonas \\ Afonso Duarte Leão de Souza \\ Federal University of Amazonas: Universidade Federal do Amazonas
}

Research Article

Keywords: Monoterpenes, Aroma, Fungal biomass, Biotransformation pathway, Biotechnological process.

Posted Date: June 1st, 2021

DOI: https://doi.org/10.21203/rs.3.rs-447822/v1

License: () (1) This work is licensed under a Creative Commons Attribution 4.0 International License. Read Full License 


\section{Abstract}

The number of aroma compounds obtained by biotechnological process has increased tremendously in recent years and, as a result, are now being extensively employed in order to make products more attractive for consumers. In the present review, we inten to assess the wide range of reactions are catalyzed by fungal strains in regards to biotransformation of limonene and pinene for the aroma compounds production, their production rates/maximum concentrations and their biological potential. We comprehensively summarized in this review available data (2000-2021) regarding fungal biotransformation of limonene and pinene as biotechnological processes. Over the past years, has been paid to the biotransformation processes due to mild and environmentally friendly conditions applied. This review has shown that reports on the application of the fungi as a promising source of biocatalysts, mainly for stereoselective reactions such as hydroxylation and epoxidation. Studies have demonstrated the existence of promising monoterpenes used as substrates, which could be important from an industrial standpoint since this increases their importance as starting materials for obtaining aromatic molecules new. Moreover, biological (e.g.,antioxidant, anticancer) activities attributed to some monoterpene biotransformation products are increasingly being reported, indicating that their applications may transcend food, cosmetic and pharmaceutical industry.

\section{Introduction}

Natural additives are a potential alternative for the replacement of traditional chemicals, and are extensively employed in the food technology, cosmetic and pharmaceutical industry. In the last few years, many chemical companies have increased their portfolios with the inclusion of naturally- obtained compounds, through the use of biotechnology-based approaches in order to substitute chemical synthesis (Oliveira Felipe, Oliveira and Bicas 2017). In this context, a joint effort between science and industry for the production of natural additives is fundamental for the development of appropriate solutions in order to meet the demand for natural compounds (Paulino et al. 2021).

Odoriferous compounds, otherwise known as aromas, have low molecular weight; generally less than $400 \mathrm{Da}$ and are organic compounds that are remarkably perceptible by smell and exert characteristic odors that are often pleasant [Pessôa et al. 2019a). These compounds are predominantly hydrophobic and are represented by their volatility and chemical diversity. They can be classified as hydrocarbons, aldehydes, alcohols, acids, ketones, esters and lactones, for example, limonene, a-pinene, and $\beta$-pinene are among the most widespread monoterpene hydrocarbons (Braga and Belo 2018; Sales et al. 2018a). A consolidated biotechnological approach comprising the production of aromatic compounds may be accomplished using the biotransformation of monoterpenes has been described (Sales et al. 2018a; Sharma et al. 2020).

During recent years, there has been increasing efforts on the part of industries to adapt their processes and products to recent global tendencies. These efforts have involved efforts to find alternatives to chemical oxidation bioprocesses for obtaining aroma compounds and include methods such as the direct extraction from nature, chemical synthesis and biotechnological transformations via microbial and enzymatic biotransformation (Molina et al. 2014a; Bicas et al. 2016e; Pessôa et al. 2019b).

Compared to chemical synthesis and direct extraction from nature, biotransformation processes are attractive and can be used to identify pathways for production of value-added compounds (Dionísio et al. 2012). The products obtained through this approach can be considered to be natural, and related to the concept of sustainable development, since such production processes are aligned with the best practices in environmental preservation (Oliveira Felipe, Oliveira and Bicas 2017)

Over the past decade, microbial biotransformations have gained importance. This biotechnology process can be defined as the use of biological systems to catalyze chemical changes in substances that do not constitute their common precursor (substrate) (Carvalho 2016; Fanaro et al. 2016). In vitro biotransformation can be carried out under mild conditions and with high selectivity, and includes regio-, stereo-, and enantioselectivity modifications of a substrate based on single or multistep reactions catalyzed by biological systems within microbial cells (bacteria, yeasts and fungi) or with pure enzymes (Molina et al. 2014a; Bicas et al. 2016e; Sales et al. 2018a). These allow the catalytic activity of these systems to act on the substrate and produce new oxygenated derivatives (Duetz et al. 2003; Sales et al. 2018d).

The main steps in the biotransformation are the selection of biocatalyst systems, which is mainly resistant and can use the precursor as the only carbon source. A huge number of biotechnological processes using whole-cell or isolated enzyme in biotransformation of monoterpenes have been published using growth in appropriate media and can generate a mixture of intermediate products (Sales et al. 2018a). Whole-cell biotransformation has the potential of being more environmentally benign than chemical synthesis and more cost-effective when compared to isolated enzyme catalysis. Among all the existing whole-cells systems, the use of fungi has traditionally been most used in biotransformation processes (Dionísio et al. 2012; Carvalho 2016).

Fungi are eukaryotic microorganisms and occur in different ecosystems around the world. They can adapt to extreme environmental conditions involving water, wastewater, oxygen, metals, organic/inorganic compounds, temperature, pH, and salinity (Borges et al. 2009; Carvalho 2016). The reactions catalyzed by fungi transcend area of chemistry and microbiology due to the fact that biocatalysts are selective, easy-to-handle, and environmentally friendly (green chemistry principles) (Oliveira Silva et al. 2013; Parshikov and Sutherland 2014; Chambergo and Valencia 2016). In addition, mounting evidence has shown that fungal cytochrome P450 (CYP) monooxygenases may be responsible for this biotransformation process. CYP dependent reactions have been proven to include hydroxylation, oxidation, epoxidation, dealkylation, dehydration, deamination, desaturation, dehalogenation and demethylation (Janocha, Schmitz and Bernhardt 2015; Zhang et al. 2016; Puentes-Cala et al. 2018). 
Many studies have focused on the selection of new fungal species that can be directly applied to biotransformation of the monoterpenes used as substrates (Pessôa et al. 2019b). Among the most targeted substrates that have potential to be used for fungal biotransformation approaches are limonene and pinene, since they may lead to the accumulation of intermediate products with high added value. These products may have a market value that is 10 to 30 times higher than the initial substrate (Carvalho 2016; Oliveira Felipe, Oliveira and Bicas 2017). Limonene has a weighted average price of US\$34/L, while its oxygenated counterparts, for example, carveol, perillyl alcohol, and carvone present reference prices of US\$ 529/L, US\$ $405 / L$, and US\$ 350/L, respectively. While a-pinene has an average price of US\$ 64/L, oxygenated derivatives, such myrtenol have reference prices of US\$1,939, verbenol (US\$1,926/L), myrtenal (US\$ 913/L) and verbenone (US\$ 906/L). Therefore, there is an important economic opportunity to be explored in the addition of value to commodities (Oliveira Felipe, Oliveira and Bicas 2017).

In this review, we inten to assess the wide range of reactions are catalyzed by fungal strains in regards to biotransformation of limonene and pinene with potential to be used as substrates, their production rates/maximum concentrations and their biological potential of these bioaromas, which parameters could be important for an industrial standpoint increasing their importance as biotechnological processes.

\section{Methodology}

For this review, existing pieces of literature (research articles, reviews and book chapter) were collected from multiple scientific journals, and worldwide databases such as Scopus, ScienceDirect, PubMed and Springer. The following keywords were searched, "Monoterpene biotransformation", "Biotransformation of limonene" "Biotransformation of pinene", "Biotransformation pathway", "biotransformations using fungi as biocatalysts", "Production of perillyl derivatives", "production of a-terpineol”, "Production of limonene-1,2-diol”, "Potential biological aroma compounds" “. Overall, more than 66 different publications (2000-2021) were collected and used for this review.

\section{Limonene And Pinene As Substrates For Fungal Biotransformation}

Over the last two decades, the biotechnological production of natural compounds has increased and has become promising for enabling the formation of aromatic compounds. Another factor that corroborates the rise of and interest in biotechnological processes for the production of aromas is the possibility of using agro-industrial residues that are rich in monoterpenoid compounds, since these can be used as substrates for biotransformation (Bicas et al. 2008a; Fanaro et al. 2016; Sharma et al. 2020).

Monoterpenes $(\mathrm{C} 10 \mathrm{H} 16)$ are hydrocarbons that are produced in the cytoplasm of plant cells, and their synthesis proceeds via the mevalonic acid pathway (MVA) starting from acetyl-CoA. All monoterpenoids are biosynthesized from geranyl diphosphate (GPP), formed by the consecutive condensation of the five-carbon monomer isopentenyl diphosphate (IPP) to its isomer dimethylallyl diphosphate (DMAPP) (Kumar et al. 2020). This diversity of isolated monoterpene molecules is derived from the cyclization processes, which enable the formation of monocyclic and bicyclic systems, and is observed in the large number of compounds reported (Dong and Jongedijk 2016; Yue et al. 2020).

The biotransformation of these monoterpenes using fungal biocatalysts is well-established, and occurs through the metabolic pathways associated to selective catalytic modifications in determined specific functional groups of limonene and pinene (Lerin et al. 2010). The monoterpenes used in biotransformation are commonly found in nature and can be acquired on a large-scale through industrial waste. In this context, limonene and pinene have been widely exploited as a precursor of different value-added aromatic compounds (Bicas et al. 2008a; Molina et al. 2014a; Sharma et al. 2020). This bioprocess has aroused interest of the scientific community, due to the satisfactory results in relation to the value-added compounds.

Among the main advantages of this biotransformation of limonene and pinene using biocatalyst systems for the production of aroma compounds, we can highlight: continuous production throughout the year without seasonal interference; adoption of parameters of processes that are less stringent (thus reducing energy costs and the use of reagents that are harmful to the environment); high enantioselectivity, which allows us to obtain aromatic compounds of high optical purity, thus beneficial to thesensory characteristics of the products; controllable and optimizable process conditions (Molina et al. 2014a; Oliveira Felipe, Oliveira and Bicas 2017).

\section{Fungal biotransformation of limonene for the production of aroma compounds}

Limonene is one of the most studied monocyclic monoterpenes and has been reported as one of the most abundant in nature. It is a chemical component of $90 \%$ of essential oils extracted from citrus fruits. S-(-)-limonene (CAS 5989-54-8) is substance that is present in lemons and Mentha sp. and R-(+)-limonene (CAS 5989-27-5) is the majority compound of fruit peel such the orange. Both of these limonene enantiomers are produced from the agro-industrial residues of these plant species and were among the first monoterpenoid compounds used as precursors for the biotechnological production of aromas (Dong and Jongedijk 2016) [28].

The oxidation process of limonene when carried out by fungi promotes selective hydroxylation reactions and enantioselective catalytic epoxidation of the carbon chain. These catalytic modifications to the functional groups of limonene produce different metabolic pathways that determine the diversity of precursors for the production of acyclic, monocyclic and bicyclic natural aroma compounds (Maróstica and Pastore 2007; Duetz et al. 2003). In this context, many studies have focused on identifying new fungi strains that have potential application in biotechnological processes through isolation, screening and selection of strains that are able to produce aroma compounds from limonene.

\section{Hydroxylation at the 7-position for production of Perillyl derivatives}


Whilst limonene enantiomers is a cheap and widely available chemical, its oxidised derivatives are relatively expensive.The biotransformation process permits the production of a hydroxymethylated monoterpene analog, for example perillyl derivatives, from a monoterpene analog having a terminal methyl group, for example limonene enantiomers, which is substantially free from other hydroxylation products (Maróstica and Pastore 2007b; Bicas, Fontanille and Larroche 2008; Carvalho et al. 2017). Specifically the allylic oxidation reaction by fungal biocatalysts to the methyl group (hydroxylation at 7-position) obtained different aroma compounds such perillyl alcohol (CAS 536-59-4), perillyl aldehyde (CAS 2111-75-3), and perillyl acid (CAS 23635-14-5) (Duetz et al. 2003; Trytek and Fiedurek 2005a; Carvalho et al. 2017).

Research and development on the biotransformation of limonene has continued to draw much attention on a wide variety of conversion products, such as perillic compounds in significant amounts, which could be more valuable to the fields of cosmetics, food ingredients and pharmaceutical industries (Lerin et al. 2010). Among the main bioconversion products, perillyl alcohol is of particular importance due to its high bulk prices that range from US\$300-600/kg (Duetz et al. 2003; Carvalho et al. 2017). It has chemopreventive properties that include treatment of cancers of the liver, mammary and lungs and, as such, suggests great market potential (Castellanos, Villamil and López 2007).

The $\mathrm{C}-\mathrm{H}$ bond activation through hydroxylation using biocatalysis of fungal CYPs is considered an important reaction of so-called late-stage functionalization that is often a challenge in organic chemistry [21, 22]. Hydroxylation can provide improved activity, selectivity, and solubility that can result in an alternative method for the achievement of bioactive analogs. Indeed, hydroxyl groups are versatile functional groups for the synthesis of intermediate natural products (Janocha, Schmitz and Bernhardt 2015; Puentes-Cala et al. 2018).

Acyclic allylic hydrogen abstraction in the methyl group of limonene enantiomers is promising due to the production of perillic derivatives, which can be characterized as natural aromatic compounds. Biotransformation of R-(+)-limonene to perillic derivatives, such as the products employing Mortierella minutíssima, has already been reported. According to the best conditions, recovery was about $0.8 \%$, with the medium adjusted to $\mathrm{pH} 6.0$, at a temperature of $20^{\circ} \mathrm{C}$ at $150 \mathrm{rpm}$, which obtained $83.5 \%$ of the principal compounds R-(+)-perillyl alcohol, R-(+)-perillyl aldehyde (2.7\%) and R-(+)-perillyl acid (13.4\%) after 5 days of reaction, as shown in Fig. 1 (Trytek and Fiedurek 2005a).

In another experiment, the use of Aspergillus niger(DSM 821) is described in the biotransformation of R-(+)-limonene and a conversion in perillyl alcohol was obtained after $72 \mathrm{~h}$ of reaction. The best fungal biotransformation pathway for limonene involves the hydroxylation at the $\mathrm{C} 7$-methyl group, resulting in the formation of perillyl alcohol and perillyl aldehyde, where two enzymes of this pathway, perillyl alcohol dehydrogenase and perillyl aldehyde dehydrogenase, were partially purified (Lerin et al. 2010).

In this study optimization of the process conditions using an integrated array of microbioreactors (250 $\mathrm{mL})$ for biotransformation of R-(+)-limonene by the psychrotrophic fungi $M$. minutissima in $\mathrm{H} 202$-oxygenated culture was reported. The best results were obtained using $0.5 \%$ of $\mathrm{R}-(+)$-limonene in $6 \mathrm{~g}$ of mycelial mass in oxygenated medium with $2 \%$ hydrogen peroxide, $\mathrm{pH} 6.0$ and $48-72 \mathrm{~h}$ cultivation at $15^{\circ} \mathrm{C} / 150 \mathrm{rpm}$. The application of $\mathrm{H} 2 \mathrm{O} 2-$ oxygenated culture for the biotransformation of limonene, under these conditions resulted in 2-fold increased productivity as compared to classical aeration and enabled precise monitoring of oxygen consumption. In this system H2O2-oxygenated culture, $258.1 \mathrm{mg} / \mathrm{L}$ of perillyl alcohol were obtained (Castellanos, Villamil and López 2007).

A yeast has been identified as Yarrowia lipolytica (ATCC 18942) in the bioconversion of R-(+)-limonene to perillic derivatives. The results were obtained using optimization of conditions, such medium supplemented with $0.5 \%(\mathrm{v} / \mathrm{v})$ of R-(+)-limonene in $\mathrm{pH} 7$, a mycelial mass of $10 \mathrm{~g} / \mathrm{L}$ and cultivation at $25^{\circ} \mathrm{C} / 200 \mathrm{rpm}$. Under these conditions, a conversion in perillyl alcohol and perillyl aldehyde was obtained The majority compound was perillyl acid and production was corresponded to $419 \mathrm{mg} / \mathrm{L}-1$ in $24 \mathrm{~h}$ and $562 \mathrm{mg} / \mathrm{L}-1$ in 48 h, respectively (Trytek, Fiedurek and Skowronek $2009 \mathrm{~b}$ ).

Another study involving the biotransformation of R-(+)-limonene used the endophytic fungi identified as the Penicillium sp. strain. Products accumulated in the medium were approximately $39.9 \mathrm{mg} / \mathrm{L}^{-1}$ of perillyl alcohol, trace accumulations of perillyl aldehyde plus two previously unknown oxygenated monoterpenoids namely p-menth-1-en-9-al and 1,3,8-p-menthatriene (Ferrara et al. 2013).

This large study presented a comparative analysis integrated between a preliminary study for biotransformation of R-(+)-limonene at $96 \%$ purity and two optimized experiments, namely the bioconversion of R-(+)-limonene at $97 \%$ purity and chemical diversification of orange oil (89\% limonene) using the yeast $Y$. lipolytica (ATCC 18942). The results in the preliminary study used six substrate additions every $48 \mathrm{~h}\left(4.0 \mathrm{~g} / \mathrm{L}^{-1}\right)$, and production of perillyl acid accumulated to $0.855 \mathrm{~g} / \mathrm{L}^{-1}$ was obtained. By contrast, between the two optimized experiments, under these experimental conditions, the principal compound perillyl acid showed concentrations of $0.796 \mathrm{~g} / \mathrm{L}^{-1}$ and $0.872 \mathrm{~g} / \mathrm{L}^{-1}$, respectively (Tappin et al. 2017).

A number of reports in the literature demonstrate that the epoxidation pathway starts with an attack to the 1,2-double bond of limonene by the enzyme limonene 1,2-monooxygenase, thus generating limonene-1,2-epoxide Limonene-1,2-epoxide hydrolase catalyzes the hydrolysis of limonene-1,2-epoxide to limonene-1,2-diol, which is an important aroma compound used in the food industry. Subsequent oxidations in limonene-1,2-diol gave rise to the compounds 1-hydroxy-2-oxolimonene, this molecule spontaneously rearranging obtained 3-isopropenyl-6-oxoheptanoate and 3-isopropenyl-6oxoheptanyl-CoA (Maróstica and Pastore 2007; Bicas, Fontanille and Larroche 2008; Carvalho et al. 2017).

Limonene-1,2-diol (CAS 1946-00-5) is a colorless to slightly yellowish oil with a fresh mint aroma. It may also be economically attractive since this product is marketed at US\$446/g, while the substrate costs US\$ 41.40/g. Limonene-1,2-diol has been associated with a significant inhibitory effect on 
the pro-inflammatory activities of CD4 + and CD8 + T lymphocytes; a potential anticancer activity. It also has insect-attractant properties besides being used as flavoring for beverages, chewing gum, gelatins, and puddings (Molina et al. 2015b; Sales et al. 2018b; Sales 2019c).

The biotransformation of both enantiomers of limonene, R-(+)- and (S)-(-)-limonene, into limonene-1,2-diol using Fusarium oxysporum (152B) has already been reported. The concentrations of limonene-1,2-diol obtained from (S)-(-)-limonene accumulated $3.7 \mathrm{~g} / \mathrm{L}^{-1}$ only peaked at after $72 \mathrm{~h}$ of reaction. Limonene-1,2-diol was not detected in the biotransformation of R-(+)-limonene. This is the first report that characterizes the bioconversion of enantiomers of limonene by cellular detoxification using ultra-structural analysis (Molina et al. 2015b).

While testing the Phomopsis sp. strain for the bioconversion of R-(+)-limonene and orange residue-based media, it was noticed that limonene-1,2-diol accumulated in the medium. The limonene-1,2-diol production followed a similar profile to that observed for both incubated substrates, with an accumulated concentration of $2.08 \mathrm{~g} / \mathrm{L}^{-1}$, which was obtained after $120 \mathrm{~h}$ of biotransformation of R-(+)-limonene. In the orange residue extract-based medium, a high concentration of limonene-1,2-diol was successfully obtained, reaching $2.10 \mathrm{~g} / \mathrm{L}^{-1}$ after $144 \mathrm{~h}$ of biotransformation with no significant increase when used for longer periods (Bier, Medeiros and Soccol 2017a).

As reported in a comparative study analyzing the biocatalytic potential of Colletotrichum nymphaeae and Colletotrichum acutatum for biotransformation of limonene enantiomers R-(+)-limonene and (S)-(-)-limonene, the authors reported the results were obtained using a mixture of both substrates at the same concentration, which were added according to the same procedure (reaching a final concentration of $5 \mathrm{~g} . \mathrm{L}^{-1}$ of substrate) by both fungi. the fungi produced traces of cis- and trans- limonene-1,2-epoxide and limonene-1,2-diol as the principal compound, as shown in Fig. 2. The biotransformation of R-(+)-limonene by $C$. acutatum and $C$. nymphaeae produced the concentrations $3 \mathrm{~g} / \mathrm{L}^{-1}$ and $4.01 \mathrm{~g} / \mathrm{L}^{-1}$ of limonene- $1,2-$ diol, respectively, after $192 \mathrm{~h}$ of fermentation. On the other hand, a similar profile was observed when (S)-(-)-limonene was applied as substrate and $C$. acutatum and $C$. nymphaeae were used as biocatalysts. Higher amounts of limonene-1,2-diol were produced $\left(3.08 \mathrm{~g} / \mathrm{L}^{-1}\right.$ and $0.06 \mathrm{~g} / \mathrm{L}^{-1}$, respectively), which were accumulated after $192 \mathrm{~h}$ (Sales et al. 2018b).

Another process for bioconversion of limonene using fungi strains was reported by Cecati et al. (2018). In this study, R-(+)-limonene was biotransformed using an endophytic fungi isolated from Eupatorium buniifolium Hook. \& Arn., identified as Alternaria alternata and Neofusicoccum sp. (EB04), which were able to produce $1.75 \mathrm{~g} / \mathrm{L}^{-1}$ and $2.23 \mathrm{~g} / \mathrm{L}^{-1}$ of limonene-1,2-diol after $72 \mathrm{~h}$, respectively, with no further significant increase in the product concentration when $\mathrm{R}-(+)$-limonene was used as substrate.

From the point of view of the productivity on a larger scale of the compound of interest limonene-1,2-diol, for biotransformation R-(+)-limonene using $C$. nymphaeae (CBMAI 0864). Moreover, a single addition of $15 \mathrm{~g} / \mathrm{L}^{-1}$ substrate $\mathrm{R}-(+)$-limonene at the start of the biotransformation resulted in the highest concentration $4.19 \mathrm{~g} / \mathrm{L}^{-1}$ of limonene-1,2-diol indicating at zero time yielded better results that fed-batch operation was not a good choice (Sales et al. 2019c). This bioconversion, mediated by $C$. nymphaeae (CBMAI 0864), has already been described. The bioprocess in the bioreactor (7.5 $L$ ) operated at $30^{\circ} \mathrm{C}, 300 \mathrm{rpm}, \mathrm{pH} 6.0$ of mineral medium and with $13 \mathrm{~g} / \mathrm{L}^{-1}$ biomass, and production reached $7.8 \mathrm{~g} / \mathrm{L}^{-1}$ and $5.6 \mathrm{~g} / \mathrm{L}^{-1}$ of accumulated limonene-1,2-diol after $72 \mathrm{~h}$ when using $20 \mathrm{~g} / \mathrm{L}^{-1}$ of R-(+)-limonene and (S)-(-) -limonene as substrate, respectively (Sales et al. 2019d).

The biotransformation of R-(+)-limonene into limonene-1,2-diol has also been reported recently for $C$. nymphaeae (CBMAI 0864). Results of extractions with different organic solvents showed that a-terpineol concentrations could reach $2.14 \mathrm{~g} / \mathrm{L}^{-1}$ ( $80.8 \%$ of recovery) when using ethyl acetate as the cosolvent, followed by $\mathrm{n}$-butanol (concentration around $1.8 \mathrm{~g} / \mathrm{L}^{-1}$ ), chloroform and dichloromethane (approximately $1.6 \mathrm{~g} / \mathrm{L}^{-1}$ each), and finally hexane $\left(0.007 \mathrm{~g} / \mathrm{L}^{-1}\right)$. This result can be explained by the fact that the intermediate polarity of ethyl acetate is the most similar to the polarity of limonene-1,2diol (Molina et al. 2019c).

Recently, a study investigated the extraction and purification of limonene-1,2-diol from biotransformation of R-(+)-limonene by $C$. nymphaeae CBMAI 0864. Results showed that aroma compounds concentrations followed a similar profile to that observed for incubated both substrates, with an accumulated concentration of $2.65 \mathrm{~g} / \mathrm{L}^{-1}$ of Limonene-1,2-diol that was obtained after $192 \mathrm{~h}$ of biotransformation (Medeiros et al. 2021). Table 1 summarizes the screening studies for limonene-1,2-diol production by fungal biotransformation of limonene enantiomers. 
Table 1

Process conditions for limonene-1,2-diol production by fungal

\begin{tabular}{|c|c|c|c|c|c|c|c|c|c|c|c|}
\hline Biocatalyst & System & $\mathrm{pH}$ & ${ }^{\circ} \mathrm{C}$ & r.p.m & $\begin{array}{l}\text { Volume } \\
\text { medium } \\
(\mathrm{mL})\end{array}$ & Substrate & $\begin{array}{l}\text { Substrate } \\
\text { concentration } \\
\left(\mathrm{g} / \mathrm{L}^{-1}\right)\end{array}$ & $\begin{array}{l}\text { Biomass } \\
\text { quantity } \\
\left(\mathrm{g} / \mathrm{L}^{-1}\right)\end{array}$ & $\begin{array}{l}\text { Product } \\
\text { formed } \\
\left(\mathrm{g} / \mathrm{L}^{-1}\right) \text {; }\end{array}$ & $\begin{array}{l}\text { Maximum } \\
\text { time (h) }\end{array}$ & References \\
\hline $\begin{array}{l}\text { Foxysporum } \\
152 \mathrm{~B}\end{array}$ & flasks & 6.5 & 28 & 250 & 200 & $\begin{array}{l}(S)-(-)- \\
\text { limonene }\end{array}$ & 5.0 & 50.0 & 3.7 & 72 & $\begin{array}{l}\text { Molina et } \\
\text { al. (2015b) }\end{array}$ \\
\hline Phomopsis sp. & flasks & n.e $e^{\star}$ & 30 & 120 & 40 & $\begin{array}{l}(R)-(+)- \\
\text { limonene }\end{array}$ & 10.0 & 3.0 & 2.1 & 120 & $\begin{array}{l}\text { Bier, } \\
\text { Medeiros } \\
\text { and } \\
\text { Soccol } \\
(2017 a)\end{array}$ \\
\hline Phomopsis sp. & flasks & n.e $e^{*}$ & 30 & 120 & 40 & Essential oil & 5.0 & 13.0 & 2.1 & 144 & $\begin{array}{l}\text { Bier, } \\
\text { Medeiros } \\
\text { and } \\
\text { Soccol } \\
(2017 a)\end{array}$ \\
\hline C. nymphaeae & flasks & 7.0 & 30 & 150 & 50 & $\begin{array}{l}(R)-(+)- \\
\text { limonene }\end{array}$ & 15.0 & 6.4 & 3.0 & 192 & $\begin{array}{l}\text { Sales et al. } \\
(2018 b)\end{array}$ \\
\hline C. acutatum & flasks & 7.0 & 30 & 150 & 50 & $\begin{array}{l}(R)-(+)- \\
\text { limonene }\end{array}$ & 15.0 & 6.2 & 4,0 & 192 & $\begin{array}{l}\text { Sales et al. } \\
(2018 b) \text {. }\end{array}$ \\
\hline C. nymphaeae & flasks & 7.0 & 30 & 150 & 50 & $\begin{array}{l}(S)-(-)- \\
\text { limonene }\end{array}$ & 15.0 & 6.4 & 3.0 & 192 & $\begin{array}{l}\text { Sales et al. } \\
(2018 b)\end{array}$ \\
\hline C. acutatum & flasks & 7.0 & 30 & 150 & 50 & $\begin{array}{l}(S)-(-)- \\
\text { limonene }\end{array}$ & 15.0 & 6.2 & 4.1 & 192 & $\begin{array}{l}\text { Sales et al. } \\
(2018 b)\end{array}$ \\
\hline $\begin{array}{l}\text { A.alternata } \\
\text { Eb03 } \\
\text { (KY968699) }\end{array}$ & flasks & 7.0 & 28 & 150 & 20 & $\begin{array}{l}(R)-(+)- \\
\text { limonene }\end{array}$ & 2.5 & 100.0 & 1.7 & 72 & $\begin{array}{l}\text { Cecati et } \\
\text { al. (2018) }\end{array}$ \\
\hline $\begin{array}{l}\text { Neofusicoccum } \\
\text { sp. EB04 }\end{array}$ & flasks & 7.0 & 28 & 150 & 20 & $\begin{array}{l}(R)-(+)- \\
\text { limonene }\end{array}$ & 2.5 & 100.0 & 2.2 & 72 & $\begin{array}{l}\text { Cecati et } \\
\text { al. (2018) }\end{array}$ \\
\hline $\begin{array}{l}\text { C.nymphaeae } \\
\text { CBMAl } 0864\end{array}$ & flasks & 7.0 & 30 & 150 & 50 & $\begin{array}{l}(R)-(+)- \\
\text { limonene }\end{array}$ & 15.0 & 6.6 & 4.2 & 192 & $\begin{array}{l}\text { Sales et al. } \\
(2019 c)\end{array}$ \\
\hline $\begin{array}{l}\text { C.nymphaeae } \\
\text { CBMAl } 0864\end{array}$ & Bioreactor & 6.0 & 27 & 300 & 6000 & $\begin{array}{l}(R)-(+)- \\
\text { limonene }\end{array}$ & 20.0 & 13.2 & 7.8 & 72 & $\begin{array}{l}\text { Sales et al. } \\
\text { (2019d) }\end{array}$ \\
\hline $\begin{array}{l}\text { C.nymphaeae } \\
\text { CBMAl } 0864\end{array}$ & Bioreactor & 6.0 & 27 & 300 & 6000 & $\begin{array}{l}(S)-(-)- \\
\text { limonene }\end{array}$ & 20.0 & 13.2 & 5.9 & 72 & $\begin{array}{l}\text { Sales et al. } \\
\text { (2019d) }\end{array}$ \\
\hline $\begin{array}{l}\text { C.nymphaeae } \\
\text { CBMAl } 0864\end{array}$ & flasks & 7.0 & 27 & 200 & 50 & $\begin{array}{l}(R)-(+)- \\
\text { limonene }\end{array}$ & 2.0 & 4.8 & 2.65 & 192 & $\begin{array}{l}\text { Medeiros } \\
\text { et al. } \\
\text { (2021) }\end{array}$ \\
\hline
\end{tabular}

*not evaluated.

\section{Epoxidation of 8,9-double bond in the isoprenil unit for production of a-terpineol}

The biotransformation processes using limonene as a substrate in the production of aroma compounds has been described and reviewed in the last few years and is considered an important approach in biotechnology. Microbial production of a-terpineol is also important and various authors reported the epoxidation reaction of the double bond in the isoprenyl-unit from limonene biotransformation (Maróstica and Pastore 2007; Tai et al. 2016).

a-terpineol (CAS 7785-53-7) has an odor typical of lilac (Syringa vulgaris Linnaeus, 1753) and a sweet smell reminiscent of peach, with an aroma threshold of 280-350 ppb. Its annual consumption is estimated to be approximately 9.2 tons, which represents an individual intake of $17.2 \mu \mathrm{g} / \mathrm{kg} / \mathrm{day}$ in the United States of America (Tai et al. 2016; Molina et al. 2019c). The traditional commercial uses of a-terpineol include household products, food technology and flavor preparations, but the increasing discoveries have been made regarding its bioactivities, such as antioxidant, anticancer, antinociceptive, anticonvulsant and sedative activities (Sousa et al. 2020; Sales et al. 2020e).

The reported food usages for a -terpineol, usually in a range of 10-20 ppm, include baked goods, chewing gum, condiments, dairy products, candies and beverages. It is an important commercial product, normally used in the formulation in soaps, cosmetics, and flavors preparations, due to the in vitro antioxidant and anti-inflammatory activities that have already been associated with this alcohol (Bicas et al. 2010c; Sousa et al. 2020).

Thus, the bioconversion processes of limonene enantiomers R-(+)-limonene and (S)-(-)-limonene were performed according to the optimized processing conditions for the production of both into a-terpineol. Among the five Penicillium digitatum strains tested, P. digitatum (ATCC 201167) has been proved to be an efficient biocatalyst to transform R-(+)-limonene to a-terpineol, and obtained a concentration of $0.93 \mathrm{~g} / \mathrm{L}^{-1}$ after $8 \mathrm{~h}$. The use of (S)-(-)-limonene 
in biotransformation experiments demonstrated that the P. digitatum (ATCC 201167) used this substrate and the compounds a-terpineol were not found or were present in low concentrations in the abiotic control, suggesting that the microorganisms were responsible for such conversions. As observed for (S)-(-)-limonene, the concentrations obtained were considered too low to justify a kinetic study (Adams, Demyttenaere and de Kimpe 2003).

Based on the use of variable screening (Plackett-Burman methodology) followed by a central composite design was described to optimize the main parameters involved. These techniques were very useful for a full understanding of the process, and presented the best conditions for the production of a-terpineol, which were $72 \mathrm{~h}$-reaction in pure distilled water as the culture medium, temperature between 24 and $28^{\circ} \mathrm{C}$, agitation of 200 to $310 \mathrm{rpm}$, R-(+)limonene concentration of $0.5 \%(\mathrm{v} / \mathrm{m})$ and an inoculum/culture medium ratio of $0.25(\mathrm{~m} / \mathrm{m})$. This is a simple and low cost process from which concentrations up to $2.4 \mathrm{~g} / \mathrm{L}-1$ of the product were obtained using Fusarium oxysporum 152b (Fig. 3) (Bicas et al. 2008b).

An integrated biotechnological process for the production of various natural products who proposed a co-production process with an optimization of conditions using F. oxysporum 152b for production of a-terpineol and alkaline lipase. This resulted in the generation of two valuable bioproducts in parallel, and it was demonstrated that the biomass stored in frozen or lyophilized forms could be used for a-terpineol production, for which the reaction rate was significantly increased in the first case (Fig. 3). Also, it was shown that the enzyme responsible for the process is enantioselective and enantiospecific for the biotransformation of S-(-)-limonene into a-terpineol, has an intracellular nature and acts in anaerobic conditions. Finally, these integrated biotechnological process obtained production of alkaline lipase in a concentration of $14 \mathrm{U} / \mathrm{mL}^{-1}$; the maximal concentration obtained for aterpineol was $4 \mathrm{~g} / \mathrm{L}^{-1}$, demonstrating it to be one of the highest already described for a fungal process. This analogous study is interesting for enzymebased industries that might use the results obtained to the benefit of their production practices (Bicas et al. 2010c).

Used a central composite design and response surface methodology to evaluate the process parameters in the biotransformation of R-(+)-limonene into a-terpineol. It is interesting to highlight that, in these processes, the biocatalysts used were Aspergillus sp. strains isolated from orchards and citric fruit industries in Brazil. The best process reached a substrate concentration of $1.75 \%$, mass of inoculum of $2 \mathrm{~g}$ and substrate to ethanol volume ratio of 1:1, with $1.7 \mathrm{~g} / \mathrm{L}^{-1}$ of a-terpineol obtained (Rottava et al. 2011).

The biotransformation of R-(+)-limonene using P. digitatum (DSM 62840) reported a a-terpineol concentration of 1,864 mg/L after $48 \mathrm{~h}$, and this production could be increased to $0.5 \%$ of substrate, inoculum/media ratio of 0.25 (w/w), in pH $3.5,27^{\circ} \mathrm{C}$ and $150 \mathrm{rpm}$ (Prieto, Perea and Ortiz 2011 ). Similarly, P. digitatum (DSM 62840) was able to produce $833.93 \mathrm{mg} / \mathrm{L}$ of limonene-1,2-diol when the pre-culture medium was in medium log-phase by adding $840 \mathrm{mg} / \mathrm{L}$ of $\mathrm{R}-(+)$-limonene dissolved in ethanol and cultivation was performed at $24^{\circ} \mathrm{C}, 150 \mathrm{rpm}$, and $\mathrm{pH} 6.0$ after $12 \mathrm{~h}$ of incubation. The addition of small amounts of R-(+)-limonene $\left(84 \mathrm{mg} / \mathrm{L}^{-1}\right)$ at the start of the fungal log-phase growth yielded a 1.5-fold yield of a-terpineol, indicating that the enzyme was inducible (Tai et al. 2016).

Recently, a study investigated the production of a-terpineol from biotransformation of R-(+)-limonene and orange residue-based media by an endophytic fungi strain identified as Phomopsis sp. Results showed that a-terpineol concentrations followed a similar profile to that observed for incubated both substrates, with an accumulated concentration of $23.64 \mathrm{mg} / \mathrm{L}^{-1}$ of a-terpineol that was obtained after $120 \mathrm{~h}$ of biotransformation. A high concentration of a-terpineol was obtained from biotransformation of an orange residue-based extract, reaching $34.22 \mathrm{mg} / \mathrm{L}^{-1}$ after $144 \mathrm{~h}$ of biotransformation with no significant increase for longer periods (Bier, Medeiros and Soccol, 2017a). Table 2 summarizes the screening studies for aterpineol production by fungal biotransformation of limonene processes. 
Table 2

Process conditions for a-terpineol production through fungal biotransformation of limonene.

\begin{tabular}{|c|c|c|c|c|c|c|c|c|c|c|c|}
\hline Biocatalyst & System & $\mathrm{pH}$ & ${ }^{\circ} \mathrm{C}$ & r.p.m & $\begin{array}{l}\text { Volume } \\
\text { medium } \\
(\mathrm{mL})\end{array}$ & Substrate & $\begin{array}{l}\text { Substrate } \\
\text { concentration } \\
\left(\mathrm{g} / \mathrm{L}^{-1}\right)\end{array}$ & $\begin{array}{l}\text { Biomass } \\
\text { quantity } \\
\left(\mathrm{g} / \mathrm{L}^{-1}\right)\end{array}$ & $\begin{array}{l}\text { Product } \\
\text { formed } \\
\left(\mathrm{g} / \mathrm{L}^{-1}\right)\end{array}$ & $\begin{array}{l}\text { Maximum } \\
\text { time (h) }\end{array}$ & References \\
\hline $\begin{array}{l}\text { P.digitatum } \\
\text { ATCC } \\
201167\end{array}$ & flasks & 3.5 & 26 & 150 & 100 & $\begin{array}{l}(R)-(+)- \\
\text { limonene }\end{array}$ & 5.7 & n.e $e^{*}$ & 0.9 & 8 & $\begin{array}{l}\text { Adams, } \\
\text { Demyttenaere } \\
\text { and de Kimpe } \\
(2003)\end{array}$ \\
\hline $\begin{array}{l}\text { P.digitatum } \\
\text { ATCC } \\
201167\end{array}$ & flasks & 3.5 & 26 & 150 & 100 & $\begin{array}{l}(S)-(-)- \\
\text { limonene }\end{array}$ & 5.7 & n. $e^{\star}$ & 0.1 & 8 & $\begin{array}{l}\text { Adams, } \\
\text { Demyttenaere } \\
\text { and de Kimpe } \\
(2003)\end{array}$ \\
\hline $\begin{array}{l}\text { F.oxysporum } \\
152 \mathrm{~b}\end{array}$ & flasks & 5.2 & 30 & 270 & 100 & $\begin{array}{l}(R)-(+)- \\
\text { limonene }\end{array}$ & 2.1 & 3.75 & 2.4 & 72 & $\begin{array}{l}\text { Bicas et al. } \\
\text { (2008b) }\end{array}$ \\
\hline $\begin{array}{l}\text { F. oxysporum } \\
152 \mathrm{~b}\end{array}$ & flasks & 6.7 & 30 & 200 & 100 & $\begin{array}{l}(S)-(-)- \\
\text { limonene }\end{array}$ & 15.0 & 3.75 & 2.0 & 48 & $\begin{array}{l}\text { Bicas et al. } \\
\text { (2010c) }\end{array}$ \\
\hline $\begin{array}{l}\text { Aspergillus } \\
\text { sp. 05.01.35 }\end{array}$ & flasks & n.e $e^{\star}$ & 30 & 175 & 30 & $\begin{array}{l}(R)-(+)- \\
\text { limonene }\end{array}$ & 1.7 & 2.0 & 1.7 & n.e $e^{*}$ & $\begin{array}{l}\text { Rottava et al. } \\
(2011)\end{array}$ \\
\hline $\begin{array}{l}\text { P. digitatum } \\
\text { DSM } 62840\end{array}$ & flasks & 6.0 & 24 & 150 & 50 & $\begin{array}{l}(R)-(+)- \\
\text { limonene }\end{array}$ & 0.9 & n. $e^{*}$ & 0.8 & 12 & $\begin{array}{l}\text { Tai et al. } \\
\text { (2016) }\end{array}$ \\
\hline $\begin{array}{l}\text { Phomopsis } \\
\text { sp. }\end{array}$ & flasks & n. $e^{\star}$ & 30 & 120 & 40 & $\begin{array}{l}(R)-(+)- \\
\text { limonene }\end{array}$ & 10.0 & 3.0 & 0.2 & 120 & $\begin{array}{l}\text { Bier, Medeiros } \\
\text { and Soccol } \\
(2017 a)\end{array}$ \\
\hline $\begin{array}{l}\text { Phomopsis } \\
\text { sp. }\end{array}$ & flasks & n. $e^{\star}$ & 30 & 120 & 40 & Essential Oil & 5.0 & 3.0 & 0.3 & 144 & $\begin{array}{l}\text { Bier, Medeiros } \\
\text { and Soccol } \\
\text { (2017a) }\end{array}$ \\
\hline $\begin{array}{l}\text { P. digitatum } \\
\text { DSM } 62840\end{array}$ & flasks & 3.5 & 27 & 150 & 5 & $\begin{array}{l}(R)-(+)- \\
\text { limonene }\end{array}$ & 2.0 & n.e $e^{*}$ & 1.8 & 48 & $\begin{array}{l}\text { Prieto, Perea } \\
\text { and Ortiz } \\
(2011)\end{array}$ \\
\hline $\begin{array}{l}\text { Aspergillus } \\
\text { sp. } 01.04 .03\end{array}$ & flasks & n. $e^{\star}$ & 30 & 175 & 30 & Essential Oil & 1.7 & 2.0 & 7.6 & n.e $e^{*}$ & $\begin{array}{l}\text { Rottava et al. } \\
(2011)\end{array}$ \\
\hline
\end{tabular}

*not evaluated.

\section{Other biotransformation of limonene for the production of aroma compounds}

However, the hydroxylation and epoxidation reactions depending on the carbon position results on production of others oxygenated compounds, can be used in the food, perfumery, cosmetic, pharmaceutical, and fuel industries (Maróstica and Pastore 2007). In various fungal biotransformation of limonene processes obtain others oxygenated compounds as carveol (CAS 99-48-9) and carvone (CAS 99-49-0) as the major product have already been reported using limonene as the substrate and fungal as biocatalysts. The carveol, together with carvone are monoterpenoids responsible for the typical odor of spearmint, which is used as an aroma and used in baked goods, chewing gums, frozen dairy, gelatin, puddings, beverages and candies, in a concentration close to $220 \mathrm{ppm}$. Its annual consumption is around 1.2 tons, representing an individual intake of $2.3 \mu \mathrm{g} / \mathrm{kg} / \mathrm{day}$ in the United States of America (Sousa et al. 2020).

The biotransformation of R-(+)-limonene by M. minutissima produce traces amounts of $(0.18 \%)$ carveol, $0.05 \%$ of limonene 1,2 -epoxide and $4.3 \%$ of carvone after $120 \mathrm{~h}$-reaction in medium adjusted to $\mathrm{pH}$ 6, temperature $20^{\circ} \mathrm{C}$, agitation at $150 \mathrm{rpm}, \mathrm{R}-(+)$-limonene concentration of $0.8 \%$ ( $/ \mathrm{m}$ ), as shown in Fig. 4, route a (Trytek and Fiedurek 2005a).

Subsequently, this study followed a central composite design was described to optimize the main parameters involved in the biotransformation by $P$. digitatum (DSM 62840). For this process, the experimental condition used was pH levels of 4.5 and 6.0 , a temperature of $27^{\circ} \mathrm{C}$ and rotation at $150 \mathrm{rpm}$, which represented the best conditions of monitored hydroxylation reactions in different carbons of R-(+)-limonene for formation of the oxygenated derivatives, such as (R)-(-)-linalool, isomers cis/trans-carveol, cis/trans-p-menth-2,8-dien-1-ol and carvone. These conditions implicated an intermediate (limonene-8,9-epoxide), which is formed via epoxidation for attack at the 8, 9-double bond catalysed by cytochrome P-450-dependent monooxygenase (Fig. 4, route b) (Prieto, Perea and Ortiz 2011).

The products identified through allylic oxidation at the $\mathrm{C} 6$ and $\mathrm{C} 3$ of $\mathrm{R}-(+)$-limonene, performed at $24^{\circ} \mathrm{C}, 150 \mathrm{rpm}$, and pH 6.0 for $24 \mathrm{~h}$ using $F$. oxysporum (CICC41029) were p-Menth-1-en-9-al, along with trace amounts of carveol. Other newly oxygenated derivatives such as dihydrocarvone, isopiperitenone and piperitenone generated after 48 h-reaction (Fig. 4, route c) (Tai et al. 2016). 
Other bioconversion processe was based on the use of Phomopsis sp. strain for the biotransformation of R-(+)-limonene and presented some compounds of interest, such as trace amounts of trans-p-mentha-2,8-dien-1ol, cis-p-mentha-2,8-dien-10l, menthol, 1,6-dihydrocarveol, trans-Carveol, cisCarveol and (R)-(-)-carvone as its principal compound, which reached a maximum concentration of $536 \mathrm{mg} / \mathrm{L}^{-1}$. Biotransformation was performed at $30^{\circ} \mathrm{C}, 120 \mathrm{rpm}$ for $120 \mathrm{~h}$ (Fig. 4, route d). However, the chemical diversification of orange residue-based media produced only minor quantities of carvone, obtaining $12.56 \mathrm{mg} / \mathrm{L}^{-1}$ after $144 \mathrm{~h}$ (Bier, Medeiros and Soccol, 2017a).

\section{Fungal biotransformation of pinene for production of aroma compounds}

The application of monotepernes as a substrate in the production of aroma compounds has been described and reviewed in the last few years and is considered an important approach in biotechnology Oliveira Felipe, Oliveira and Bicas 2017). The reasons for this is that monoterpenes are abundantly found in industrial wastes - for example, pinene is a bicyclic monoterpene and can be found in two isomeric forms, a-pinene and $\beta$-pinene. This chemical compounds of several essential oils, such as turpentine oils obtained from conifers (Salehi et al. 2019).

a-Pinene (CAS 67762-73-6) is a colorless liquid that is soluble in ethanol and oils, and insoluble in water, with a boiling point of $155^{\circ} \mathrm{C}$. At a concentration of $1 \%$, it has a citrus, spicy, woody pine, and turpentine-like aroma. The threshold of detection is 2.5 to $62 \mathrm{ppb}$. The gustative threshold is $10 \mathrm{ppm}$, and it presents an intense, woody, piney taste with a notable camphor-like and turpentine taste. $\beta$-Pinene (CAS 18172-67-3) is a colorless liquid that is soluble in oils and insoluble in water and ethanol, with a boiling point between 163 and $166^{\circ} \mathrm{C}$. At a concentration of $10 \%$, the aroma characteristics are cooling, woody, piney, and turpentine, with traces of fresh mint, eucalyptus, and camphor. It can be detected at a threshold of 140 $\mathrm{ppb}$. As for its taste, it has a characteristically fresh, pine, woody, and resinous taste at 15 to $100 \mathrm{ppm}$ and a slightly spicy nuance of mint, and camphor (Vespermann et al. 2017; Xu et al. 2019; Kenseth et al. 2020).

The different levels of pinenes in turpentine may vary according to the botanical species, but in general, the amount of a-pinene is always higher than that of $\beta$-pinene in the studied oils. Turpentine oil is an agro-industrial waste, which stands out as a residue rich in pinenes, and due to the affordable price, is ideal in biotechnological processes for production of value-added bioflavors widely used in cosmetic and food industries. Thus, many studies describe the biotransformation of pinenes into bioflavors compounds using different fungal biocatalysts, that has been cited as a promising approach (Molina et al. 2014a; Paulino et al. 2021).

\section{Biotransformation of pinene from the production of aroma compounds.}

Besides the monoterpenes mentioned, $a$-pinene and $\beta$-pinene have been used as substrate in biotransformation processes for production of important aroma compounds, including verbenol, verbenone, myrtenol and a-terpineol (Sales et al. 2018a). Thus, various types of process optimization have been successfully implemented on the laboratorial scale, with the use of biphasic systems, to provide a better dissolution of substrate and increase the permeability of the cells to organic solvents to facilitate the diffusion of the product to the extracellular media (Vespermann et al. 2017; Kutyła et al. 2020).

Several strategies described for the biotransformation of $\beta$-pinene in the production of $a$-terpineol using wild strains that were selected in a screening study performed with more than 400 microorganisms. Among the microorganisms studied, A. niger (ATCC 16404) was incubated with 30 mL of PD media at $25^{\circ} \mathrm{C}$ and $150 \mathrm{rpm}$ and, under these conditions, it was able to produce around $2,856.54 \mathrm{mg} / \mathrm{L}$ of a-terpineol and traces of pinocamphone, fenchol, trans-pinocarveol, borneol and cycle-hexanemethanol after $72 \mathrm{~h}$ of reaction While under another experimental condition, at $35^{\circ} \mathrm{C}$ and $150 \mathrm{rpm}$ without addition of a vitamin solution, it yielded a conversion into a-terpineol of 15,494.34 $\mathrm{mg} / \mathrm{L}$ during 6 days. Furthermore, other species of $A$. niger (ATCC 9642) and A. niger (ATCC 1004) could biotransform $\beta$-pinene to a-terpineol reaching concentrations up to $688.13 \mathrm{mg} / \mathrm{L}$ and $172.07 \mathrm{mg} / \mathrm{L}$ after $192 \mathrm{~h}$, respectively (Rottava et al. 2010a).

Researchers of previous studies have exploring the biotechnological potential of the $\beta$-pinene aiming at the production of a-terpineol by Aspergillus sp. (strains coded as 04.05 .08 and 01.04 .03 ) using the central composite rotatable design (CCRD) methodology. The best process conditions reached were a substrate concentration of $1.75 \%$, mass of inoculum of $2 \mathrm{~g}$ and substrate to ethanol volume ratio of $1: 1$. Under these conditions, the concentration of a-terpineol in the culture medium was reached using Aspergillus sp. (04.05.08) and (01.04.03), and higher production was also obtained in the central point of the experimental design, about $761 \mathrm{mg} / \mathrm{L}$ and $763 \mathrm{mg} / \mathrm{L}$, respectively (Rottava et al. 2011b).

Other pathways that lead to the formation of oxygenated derivatives occurs through of the biotransformation of a-pinene. Several oxygenated bioproducts were obtained from of comparative study of the biotransformation of a-pinene isomers by cultures of Fusarium solani (Eb01) and Neofusicoccum sp. (Eb04). In Fig. 5, route a, the potential biotransformations of $a-(-)$-pinene and $a-(+)$-pinene by culture of $F$. solani, were obtained several oxygenated monoterpenes as terpinen-4-ol (33\% and 50.3\%); a-terpineol (3\% and $2.4 \%)$; cis-sabinene hydrate (1.1\% and $0.5 \%)$, respectively. While, the biotransformations of $a-(-)$-pinene and $a-(+)$-pinene to limone-1,2-diol (39.7\% and 34.6\%), borneol (7.6\% and 8.7), p-menth-1-em-7-al (3.1\% and $0.6 \%$ ) e exo-fenchol (2.4\% and 6.0\%) were performed using culture Neofusicoccum sp. (EB04) visualized in Fig. 5., route g. These compounds were identified after $72 \mathrm{~h}$ of incubation and characterized using GC-MS and quantified using GC-FID (Cecati et al. 2018).

As shown in Fig. 5, route b, the main oxygenated monoterpenes obtained by biotransformation of a-pinene using Ceriporia sp were a-terpineol (30.38\%) as majority compound, at a concentration of $0.05 \mathrm{~g} / \mathrm{L}$, with minor products, such as fenchol (17.78\%), borneol (7.19\%), limonene (3.90\%), verbenone (3.03\%), 1-octen-3-ol (0.43\%) and 3-octanone (0.21\%), also identified. Another study, which used the strain Stereum hirsutum (KFRI 234), suggested that the biotransformation of a-pinene has to undergo a dehydrogenation reaction in order to form verbenone (27.64\%) and myrtenol (CAS 515-00-4) 
(17.75\%), with minor products, such as camphor (CAS 464-49-3) (8.49\%) and pinocarveol (CAS 5947-36-4) (3.10\%), after 96 h (Fig. 5, route d) (Lee et al. 2015a).

The fungus Polyporus brumalis (KFRI 20912) initiate the metabolism of a-pinene through the oxidation of the double bond at carbons 8-9, forming an epoxide and the hydration. This reaction is catalyzed by $P$. brumalis resulted in the formation of $a$-terpineol (35.85\% - 39.05\%), with minor products also identified, such as borneol (CAS 507-70-0) (8.59\%) and fenchol (CAS 1632-73-1) (5.54\%), after five days of reaction (Fig. 5, route f) (Lee et al. 2015b).

Cultures of psychrotrophic fungus Chrysosporium pannorum (A-1), shows promise for allylic hydroxylation in C-3-position of a-pinene. The metabolites obtained from this process were verbenol (CAS 473-67-6) and verbenone (CAS 5480-12-6) (Fig. 5, route e). The highest concentrations of verbenol, about $722 \mathrm{mg} / \mathrm{L}$, were reached using $1.5 \%(\mathrm{v} / \mathrm{v})$ of substrate and 72-h-old mycelium, whereas the best result for verbenone (about $176 \mathrm{mg} / \mathrm{L})$ was obtained using $1 \%(\mathrm{v} / \mathrm{v})$ of substrate and 48 -h-old mycelium. The sequential addition of substrate proved to be a very efficient strategy to increase the yield because it was 3-fold higher than that obtained with a single addition of substrate after $72 \mathrm{~h}$, reaching a concentration of $1.3 \mathrm{~g} / \mathrm{L}$, summing verbenol and verbenone (Trytek, Jędrzejewski and Fiedurek 2015c).

Trytek, Fiedurek and Gromada (2016d) studied the effect of cell induction with the monoterpene substrate (1\% v/v) and the use of dioxane, chloroform and etanol as co-solvent in the process of bioconversion of a-pinene to verbenol, verbenone and trans-pinocarveol (Fig. 5, route h) by psychrotrophic $C$. pannorum. The best results were obtained with cells that were not precultivated with the substrate (non-inducted), in the presence of ethanol and with gradual addition of substrate. Accordingly, it was proposed that that the addition of substrate should be gradual to minimize the eventual toxicity and subsequent inhibition of biocatalyst cells, and thereby, facilitate the biotransformation of a-pinene.

In a recent study, the biotransformation of a-pinene by cell cultures of $A$. niger(NRRL 326) resulted in the formation of mainly (S)-(+)-carvone hydrate (4.28\%) according to the GC-MS analysis, after a period of 4 days, when all the a-pinene had been consumed (Fig. 5, route c) (Çorbacı 2020). Many authors have proposed schematic representations of the main metabolic pathways of interest which produce these respective derivatives and these are shown in Fig. 5.

Because of the wide range of products of commercial interest that can be produced from $\alpha$ - and $\beta$-pinene, studies on the biotransformation of these compounds have been stimulated for decades. From a technological point of view, the biotransformation of $\alpha$ - and $\beta$-pinene has already shown great advances in recent years, although there are still challenges to be overcome by the aroma and fragrance industries (Vespermann et al. 2017).

\section{Potential biological aroma compounds produced using fungal biotransformation of limonene and pinene..}

In this section, we will discuss biological potential of bioaromas that can transcend the food industry, and be of use in the pharmaceutical industry. However, in the scientific literature, there are few papers that describe and review the biological potential of aroma compounds produced by the fungal biotransformation of limonene and pinene.

The natural aroma compounds produced also have biological proprieties, such antioxidant potential. The a-terpineol, perillyl acohol and carvone present in the limonene biotransformation extract were assessed using four antioxidant assays (Junior et al. 2009). The results of this study of Junior et al (2009) show that the limonene biotransformation extract had free radical-scavenging activity $\left(\mathrm{EC}_{50}=2.09 \%, \mathrm{v} / \mathrm{v}\right)$ and inhibited lipid peroxidation $\left(\mathrm{IC}_{50}=0.13 \%, \mathrm{v} / \mathrm{v}\right)$. The extract, perillyl alcohol and a-terpineol, inhibited lipid peroxidation by $~ 80 \%$ at a concentration of $0.02 \%(\mathrm{v} / \mathrm{v})$. Perillyl alcohol and a-terpineol also reduced the release of superoxide anions by cultured leukemic cells, by 3 - and 10 -fold, respectively, at concentrations of < $0.02 \%$ (v/v). The biotransformation extract inhibited the conversion of nitrophenyl acetate to $\mathrm{p}$-nitrophenol in the glutathione assay by 50\%. Junior et al [53] point out that this study has the possibility of using a crude extract as an antioxidant would greatly reduce the need to obtain pure compounds via expensive industrial purification techniques. This findings also suggest that some natural aroma compounds may be useful as functional bioaromas in health supplements and nutraceuticals.

Bicas et al. (2011d) reported the antioxidant potential of carvone, perillyl alcohol, and a-terpineol using the antioxidant assays DPPH and ORAC. In addition, the evaluation of the antiproliferative capacity of this alcohol against nine cancerous cell lines were performed and compared to limonene and doxorubicin. The results of this study showed that all the samples tested had very low antioxidant activity in the DPPH assay, but a-terpineol (2.72 $\mu$ mol Trolox equiv./ $\mu \mathrm{mol}$ ) could be compared to commercial antioxidants in the ORAC assay. The antiproliferative results obtained encourage future in vivo studies for a-terpineol, since this monoterpenoid presented cytostatic effect against six cell lines, especially for breast adenocarcinoma and chronic myeloid leukemia, in a range of $181-588 \mu \mathrm{M}$.

Other evaluations of antioxidant activity have been reported by Bier et al. (2019). This study was based on antioxidant potential of a product from the biotransformation of R-(+)-limonene using the antioxidant assays DPPH, ORAC and CUPRAC. According to the results obtained using the DPPH method, the limonene biotransformation extract presented $20.17 \%$ antioxidant activity, compared to $12.1 \%$ from the orange waste extract, while, from the ORAC analysis, the results were $24,011.39 \mu \mathrm{molTE} / \mathrm{g}$, obtained from the limonene biotransformation extract in comparison to $5226.45 \mu \mathrm{molTE} / \mathrm{g}$ from the orange waste. The results from the CUPRAC analysis were $538.05 \mathrm{mg}$ TE/g from dry extract from the limonene biotransformation extract in comparison to $168.27 \mathrm{TE} / \mathrm{g}$ of dry extract from the orange waste.

An experimental model of obesity, as reported by De Sousa et al. (2020), was created to investigate whether a diet containing a-terpineol could attenuate metabolic disorders caused by a hyperlipidic diet and also identify possible differences in the physiological responses for a-terpineol

Page 10/17 
enantiomers.

The results of this experimental study showed that a-terpineol improved the nutritional parameters of rats fed a high-fat diet. Moreover, the intake of aterpineol at concentrations $>50 \mathrm{mg} / \mathrm{kg}$ was able to reestablish the insulin sensibility and reduced $(p<0.05)$ serum levels of the proinflammatory cytokines TNF- $\alpha$ and IL-1 $\beta$, when compared with the control group. The intake of R-(+)- and (-)-a-terpineol decreased the TNF-a level by approximately 1.5 and 3.4 times, respectively, when compared with the high-fat group, regardless of the concentration. Furthermore, both enantiomers at $50 \mathrm{mg} / \mathrm{kg}$ decreased the levels of serum TBARS by 2.6-4.2 times, while hepatic TBARS were reduced in approximately 1.6 times, regardless of the compound and concentration tested De Sousa et al. (2020).

More recently, Çorbaci (2020) reported the antioxidant potential of a-pinene biotransformation extract using the antioxidant assays DPPH and ORAC. The antimicrobial activities of the a-pinene biotransformation extracts against the test pathogenic microorganisms were evaluated by both disc diffusion and MIC methods. The biological activities of the extracts were found to be slightly higher than the control experiments. The findings obtained will contribute to the literature and $A$. niger (NRRL 326) has the potential to become an important biotransformation agent.

\section{Concluding Remarks}

In this review, it can be observed that the studies published during the last two decades have illustrated the various facets of the processes of the fungal biotransformation of limonene and pinene. The use these suitable substrates is an environmentally-friendly and cost-effective alternative. On the application of the fungi is a growing approach in the chemical and microbiology fields, due to the fact theses fungal biocatalysts are selective, easy-to-handle, and environmentally friendly for the production of natural aroma compounds.

Some fungi have shown promise for the biotransformation of limonene and pinene, such as of the F. oxysporum 152b, P. digitatum (ATCC 201167) C. nymphaeae and $C$. acutatum leading to the production of compounds of high economic value with satisfactory yields. The discovery of new fungi, such as $C$. pannorum, which act under very mild conditions and may facilitate the work with volatile substrates, is noteworthy. Moreover, biological (e.g.,antioxidant, anticancer) activities attributed to some monoterpene biotransformation products are increasingly being reported, indicating that their applications may transcend food, cosmetic and pharmaceutical industry.

Although fungal biotransformation of limonene and pinene is a promising biotechnological approach, many challenges still need to be overcome, such as low solubility, volatility, and toxicity of the substrates as well as the low product concentrations, and thus, it is expected that the joint application of the selection of new microorganisms, process optimization techniques, and the possibility of scaling-up may facilitate the production of compounds labeled as natural from such versatile and cheap substrates as the limonene and pinene.

\section{Abbreviations}

Da - Dalton; CG/MS - Gas Chromatography/mass spectrometry; CG/FID - Gas chromatography/flame ionization detector; CAS - Chemical Abstracts Service; MIC - Minimum inhibitory concentration; TBARS - Thiobarbituric acid reactive substances; IL-1 $\beta$ - Interleukin 1 beta; TNFa - Tumor necrosis factor alpha; DPPH - 2,2-diphenyl-1-picrylhydrazyl; ORAC - oxygen radical absorbance capacity; CUPRAC - CUPric reducing antioxidant capacity

\section{Declarations}

\section{Acknowledgements}

The authors would like to thank the Fundação de Amparo à Pesquisa do Estado do Amazonas (FAPEAM, Brazil) for the financial support of this research.

\section{Conflicts of Interest}

The authors declare no conflict of interest

\section{Credit authorship contribution statement}

E. S. Sevalho wrote the manuscript. B. N. Paulino revised the manuscript. A. Q. L. Souza revised the manuscript. A. D. L. Souza guided the writing and revision of this review.

\section{Ethical statement}

This article does not contain any studies with human or animal participants performed by any of the authors.

\section{References}

Adams A, Demyttenaere JC, De Kimpe N (2003) Biotransformation of (R)-(+)-and (S)-(-)-limonene to a-terpineol by Penicillium digitatum- investigation of the culture conditions. Food Chem 80(4):525-534. https://doi.org/10.1016/S0308-8146(02)00322-9. 
Bicas JL, Fontanille P, Pastore GM, Larroche C (2008a) Characterization of monoterpene biotransformation in two pseudomonads. J Appl Microbiol 105(2):1991-2001. https://doi.org/10.1111/j.1365-2672.2008.03923.x.

Bicas JL, Barros FFC, Wagner R, Godoy HT, Pastore GM (2008b). Optimization of R-(+)-a-terpineol production by the biotransformation of R-(+)limonene. J Ind Microbiol Biotechnol 35(9):1061-1070. https://doi.org/10.1007/s10295-008-0383-0.

Bicas JL, De Quadros CP, Néri-Numa IA, Pastore GM (2010c). Integrated process for co-production of alkaline lipase and R-(+)-a-terpineol by Fusarium oxysporum. Food Chem 120(2): 452-456. https://doi.org/10.1016/j.foodchem.2009.10.037.

Bicas JL, Neri-Numa IA, Ruiz ALTG, De Carvalho JE, Pastore GM (2011d) Evaluation of the antioxidant and antiproliferative potential of bioflavors. Food Chem Toxicol 49(7):1610-1615. https://doi.org/10.1016/j.fct.2011.04.012.

Bicas JL, Molina G, Barros FFC, Pastore GM (2016e). In: Coelho MA, Ribeiro BD (eds) Production of aroma compounds by white biotechnology. The Royal Society of Chemistry, London. https://doi.org/10.1039/9781782624080.

Bier MCJ, Medeiros ABP, Soccol CR (2017a) Biotransformation of limonene by an endophytic fungus using synthetic and orange residue-based media. Fungal Biol 121(2): 137-144. https://doi.org/10.1016/j.funbio.2016.11.003.

Bier MCJ, Medeiros ABP, De Kimpe N, Soccol CR (2019b) Evaluation of antioxidant activity of the fermented product from the biotransformation of R(+)-limonene in solid-state fermentation of orange waste by Diaporthe sp. Biotechnol Res Innov 3(1): 168-176.

https://doi.org/10.1016/j.biori.2019.01.002.

Borges KB, De Souza Borges W, Durán-Patrón R, Pupo MT, Bonato PS, Collado IG. (2009). Stereoselective biotransformations using fungi as biocatalysts. Tetrahedron: Asymmetry 20(4):385-397. https://doi.org/10.1016/j.tetasy.2009.02.009.

Braga A, Guerreiro C, Belo I (2018) Generation of flavors and fragrances through biotransformation and de novo synthesis. Food Bioprocess Technol 11(12):2217-2228. https://doi.org/10.1007/s11947-018-2180-8.

Carvalho EG, Siani AC, Cardoso IC, Correia VG, Ferrara MA, Bon EP, Tappin MRR (2017) Determination of Perillic Acid in Bioconversion Supernatants by Gas Chromatography. Am J Anal Chem 8(10): 636-644. https://doi.org/10.4236/ajac.2017.810046.

Castellanos FE, Villamil AP, López CO (2007). Obtención de alcohol perílico por biotransformación del limoneno. Scientia et technica 1(33):137-140. https://doi.org/10.22517/23447214.6161.

Cecati FM, Magallanes-Noguera C, Tonn CE, Ardanaz CE, Kurina-Sanz M (2018) Ecofriendly chemical diversification of Eupatorium buniifolium essential oil by endophytic fungi. Process Biochem 64:93-102. https://doi.org/10.1016/j.procbio.2017.09.028.

Chambergo FS, Valencia EY (2016) Fungal biodiversity to biotechnology. Appl Microbiol Biotechnol, 100(6): $2567-2577$.

https://doi.org/10.1007/s00253-016-7305-2.

Çorbacı C (2020) Biotransformation of terpene and terpenoid derivatives by Aspergillus niger NRRL 326. Biologia 75:1473-1481. https://doi.org/10.2478/s11756-020-00459-1.

De Carvalho CCCR (2016) In: Li DW (ed) Fungi in fermentation and biotransformation systems. Springer, Londres https://doi.org/10.1007/978-3-31929137-6_21.

De Medeiros TDM, Alexandrino TD, Pastore GM, Bicas JL (2021) Extraction and purification of limonene-1, 2-diol obtained from the fungal biotransformation of limonene. Separ Purif Tech, 254: 117683. https://doi.org/10.1016/j.seppur.2020.117683.

De Oliveira Silva E, Furtado NAJC, Aleu J, Collado IG (2013) Terpenoid biotransformations by Mucor species. Phytochemistry Rev 12(4):857-876. https://doi.org/10.1007/s11101-013-9313-5.

De Sousa GM, Cazarin CBB, Junior MRM, De Almeida Lamas C, Quitete VHAC, Pastore G. M, Bicas JL (2020) The effect of a-terpineol enantiomers on biomarkers of rats fed a high-fat diet. Heliyon 6(4): e03752. https://doi.org/10.1016/j.heliyon.2020.e03752.

Di Nardo G, Gilardi G (2020) Natural compounds as pharmaceuticals: the key role of cytochromes P450 reactivity. Trends Biochem Sci 45(6):511-525. https://doi.org/10.1016/j.tibs.2020.03.004.

Dionísio AP, Molina G, De Carvalho DS, Dos Santos R, Bicas JL, Pastore G. M (2012) In: David Baines D, Seal R (eds) Natural flavourings from biotechnology for foods and beverages. Woodhead Publishing, London. https://doi.org/10.1533/9780857095725.1.23.

Dong L, Jongedijk E, Bouwmeester H, Van Der Krol A (2016) Monoterpene biosynthesis potential of plant subcellular compartments. New Phytologist 209(2):679-690. https://doi.org/10.1111/nph.13629. 
Duetz WA, Bouwmeester H, Van Beilen JB, Witholt B (2003) Biotransformation of limonene by bacteria, fungi, yeast, and plants. Appl Microbiol Biotechnol 61:269-277. https://doi.org/10.1007/s00253-003-1221-y.

Fanaro GB, Fontanille, P, Maróstica Júnior MR, Bicas JL (2016) In: Bicas JL, Maróstica Júnior MR., Pastore GM (eds) Biotechnological aroma compounds. Bentham Science Publishers, Emirados Árabes Unidos. https://doi.org/10.1007/978-981-13-7154-7_3.

Ferrara MA, Almeida DS, Siani AC, Lucchetti L, Lacerda PS, Freitas A, Tappin MRR, Bon EP (2013) Bioconversion of R-(+)-limonene to perillic acid by the yeast Yarrowia lipolytica. Braz J Microbiol 44(4):1075-1080. http://dx.doi.org/10.1590/S1517-83822014005000008.

Janocha S, Schmitz D, Bernhardt R (2015) In: Schrader J, Bohlmann J (eds) Terpene hydroxylation with microbial cytochrome p450 monooxygenases. Springer, Londres https://doi.org/10.1007/10_2014_296.

Jongedijk E, Cankar K, Buchhaupt M, Schrader J, Bouwmeester H, Beekwilder J (2016) Biotechnological production of limonene in microorganisms. Appl Microbiol Biotechnol 100(7): 2927-2938. https://doi.org/10.1007/s00253-016-7337-7.

Junior MRM, Silva TAR, Franchi GC, Nowill A, Pastore GM, Hyslop S (2009) Antioxidant potential of aroma compounds obtained by limonene biotransformation of orange essential oil. Food Chem 116(1):8-12. https://doi.org/10.1016/j.foodchem.2009.01.084.

Kenseth CM, Hafeman NJ, Huang Y, Dalleska NF, Stoltz BM, Seinfeld JH (2020) Synthesis of carboxylic acid and dimer ester surrogates to constrain the abundance and distribution of molecular products in a-pinene and $\beta$-pinene secondary organic aerosol. Environ Sci Tech 54(20): 12829-12839. https://doi.org/10.1021/acs.est.0c01566.

Kumar SR, Rai A, Bomzan DP, Kumar K, Hemmerlin A, Dwivedi V, Godbole RC, Barvkar V, Shanker K, Shilpashree HB, Bhattacharya A, Smitha AR, Hegde N, Nagegowda DA (2020) A plastid-localized bona fide geranylgeranyl diphosphate synthase plays a necessary role in monoterpene indole alkaloid biosynthesis in Catharanthus roseus. Plant J 103(1): 248-265. https://doi.org/10.1111/tpj.14725.

Kutyła M, Fiedurek J, Gromada A, Jędrzejewski K, Trytek M (2020) Mutagenesis and adaptation of the psychrotrophic fungus Chrysosporium pannorum A-1 as a method for improving $\beta$-pinene bioconversion. Molecules 25(11): 2589. https://doi.org/10.3390/molecules25112589.

Lee SY, Kim SH, Hong CY, Kim HY, Ryu SH, Choi IG (2015a) Biotransformation of (-)-a-Pinene by Whole Cells of White Rot Fungi, Ceriporia sp. ZLY-2010 and Stereum hirsutum. Mycobiology 43(3):297-302. https://doi.org/10.5941/MYC0.2015.43.3.297.

Lee SY, Kim SH, Hong CY, Park SY, Choi IG (2015b) Biotransformation of (-)-a-pinene and geraniol to a-terpineol and p-menthane-3, 8-diol by the white rot fungus, Polyporus brumalis. J Microbiol 53(7): 462-467. https://doi.org/10.1007/s12275-015-5081-9.

Lerin L, Toniazzo G, Oliveira D, Rottava L, Dariva C, Cansian RL, Treiche H, Padilha F, Antunes OAC (2010). Microorganisms screening for limonene oxidation. Food Sci Tech, 30(2):399-405. http://dx.doi.org/10.1590/S0101-20612010000200017.

Maróstica Júnior MR, Pastore GM (2007) Biotransformação de limoneno: uma revisão das principais rotas metabólicas. Quim Nova 30(2):382-387 https://doi.org/10.1590/S0100-40422007000200027.

Molina G, Pêssoa MG, Pimentel MR, Pelissari FM, Bicas JL, Pastore GM (2014a) In: Hu J (ed) Production of natural flavor compounds using monoterpenes as substrates, 1rd edn. Nova Publishers, New York

Molina,G, Bution ML, Bicas JL, Dolder MAH, Pastore GM (2015b) Comparative study of the bioconversion process using R-(+)-and S-(-)-limonene as substrates for Fusarium oxysporum 152B. Food Chem 174:606-613 https://doi.org/10.1016/j.foodchem.2014.11.059.

Molina G, Pessôa MG, Bicas JL, Fontanille P, Larroche C, Pastore GM (2019c) Optimization of limonene biotransformation for the production of bulk amounts of a-terpineol. Bioresour Technol 294: 122180. https://doi.org/10.1016/j.biortech.2019.122180.

Oliveira Felipe L, De Oliveira, AM, Bicas, JL (2017). Bioaromas-Perspectives for sustainable development. Trends Food Sci Tech 62:141-153 https://doi.org/10.1016/j.tifs.2017.02.005.

Parshikov IA, Sutherland JB (2014) The use of Aspergillus niger cultures for biotransformation of terpenoids. Process Biochem 49(12):20862100.https://doi.org/10.1016/j.procbio.2014.09.005.

Paulino BN, Sales A, Oliveira Felipe L, Pastore GM, Molina, G, Bicas JL (2020) Recent advances in the microbial and enzymatic production of aroma compounds. Curr Opin Food Sci 37:98-106. https://doi.org/10.1016/j.cofs.2020.09.010.

Pessôa MG, Paulino BN, Molina G, Pastore GM (2019a). In: Molina G, Gupta V, Singh B, Gathergood N (eds) Prospective research and current technologies for bioflavor production. John Wiley \& Sons Ltd, Nova Jersey. https://doi.org/10.1002/9781119434436.ch5.

Pessôa MG, Vespermann KA, Paulino BN, Barcelos MC, Pastore GM, Molina, G (2019b) Newly isolated microorganisms with potential application in biotechnology. Biotechnol Adv 37(2):319-339. https://doi.org/10.1016/j.biotechadv.2019.01.007.

Page 13/17 
Prieto GA, Perea JA, Ortiz CC (2011) Microbial biotransformation of (R)-(+)-limonene by Penicillium digitatum DSM 62840 for producing (R)-(+)terpineol. Vitae 18(2): 163-172.

Puentes-Cala E, Liebeke M, Markert S, Harder J (2018) Limonene dehydrogenase hydroxylates the allylic methyl group of cyclic monoterpenes in the anaerobic terpene degradation by Castellaniella defragrans. Int J Biol Chem 293(24):9520-9529. https://doi.org/10.1074/jbc.RA117.001557.

Rottava I, Toniazzo G, Cortina PF, Martello E, Grando CE, Lerin LA, Treichel H, Mossic AJ, de Oliveira D, Cansian RL, Antunes OAC, Oestreichera EG (2010a) Screening of microorganisms for bioconversion of (-) $\beta$-pinene and R-(+)-limonene to a-terpineol. LWT-Food Sci Technol 43(7): $1128-1131$. https://doi.org/10.1016/j.Iwt.2010.03.001.

Rottava I, Cortina PF, Martello E, Cansian RL, Toniazzo G, Antunes OA, Enrique G. Oestreicher EG, Treichel H, De Oliveira D (2011b) Optimization of aterpineol production by the biotransformation of R-(+)-Limonene and (-)-B-Pinene. Appl Biochem Biotechnol 164(4): 514-523.

https://doi.org/10.1007/s12010-010-9153-3.

Salehi B, Upadhyay S, Orhan IE, Jugran AK, Jayaweera SLD, Dias DA, Sharopov F, Taheri Y, Martins N, Baghalpour N, Cho WC, Sharifi-Rad J (2019) Therapeutic potential of a-and $\beta$-pinene: a miracle gift of nature. Biomolecules 9(11): 738. https://doi.org/10.3390/biom9110738.

Sales A., Paulino BN, Pastore GM, Bicas JL (2018a) Biogeneration of aroma compounds. Curr Opin Food Sci 19:77-84. https://doi.org/10.1016/j.cofs.2018.03.005.

Sales A, Afonso LF, Americo JA, De Freitas Rebelo M, Pastore GM, Bicas JL (2018b) Monoterpene biotransformation by Colletotrichum species. Biotechnol Lett 40(3): 561-567. https://doi.org/10.1007/s10529-017-2503-2.

Sales A, Moreira RC, Pastore GM, Bicas JL (2019c) Establishment of culture conditions for bio-transformation of R-(+)-limonene to limonene-1, 2-diol by Colletotrichum nymphaeae CBMAI 0864. Process Biochem 78: 8-14. https://doi.org/10.1016/j.procbio.2019.01.022.

Sales A, Pastore GM, Bicas JL (2019d) Optimization of limonene biotransformation to limonene-1, 2-diol by Colletotrichum nymphaeae CBMAI 0864. Process Biochem 86:25-31. https://doi.org/10.1016/j.procbio.2019.07.022.

Sales A, Felipe LDO, Bicas JL (2020e) Production, properties, and applications of a-terpineol. Food Bioprocess Technol 13:1261-1279. https://doi.org/10.1007/s11947-020-02461-6.

Sharma A, Sharma P, Singh J, Singh S, Nain L (2020) Prospecting the potential of agroresidues as substrate for microbial flavor production. Front Sustain Food Syst 4(18):1-11. https://doi.org/10.3389/fsufs.2020.00018.

Sousa C, Leitão AJ, Neves BM, Judas F, Cavaleiro C, Mendes AF (2020) Standardised comparison of limonene-derived monoterpenes identifies structural determinants of anti-inflammatory activity. Sci Rep 10(1): 1-14. https://doi.org/10.1038/s41598-020-64032-1.

Tai YN, Xu M, Ren JN, Dong M, Yang ZY, Pan SY, Fan G (2016) Optimisation of a-terpineol production by limonene biotransformation using Penicillium digitatum DSM 62840. J Sci Food Agr 96(3): 954-961. https://doi.org/10.1002/jsfa.7171.

Tappin MR, Knopp FM, Cardoso IC, Santos RT, Drummond BS, Siani AC, Bon EPS, Ferrara MA (2017) Synthesis of the prospective anticancer molecule perillic acid from orange essential oil by the yeast Yarrowia lipolytica. Green Sustain Chem 7(2):172-184. https://doi.org/10.4236/gsc.2017.72013.

Trytek M, Fiedurek J (2005a) A novel psychrotrophic fungus, Mortierella minutissima, for D-limonene biotransformation. Biotechnol Lett 27(3):149-153. https://doi.org/10.1007/s10529-004-7347-x.

Trytek M, Fiedurek J, Skowronek M (2009b) Biotransformation of (R)-(+)-limonene by the psychrotrophic fungus Mortierella minutissima in H2O2oxygenated culture. Food Tech Biotechnol, 47(2):131-136. 33.

Trytek M, Jędrzejewski K, Fiedurek J (2015c) Bioconversion of a-pinene by a novel cold-adapted fungus Chrysosporium pannorum. J Ind Microbiol Biotechnol 42(2):181-188. https://doi.org/10.1007/s10295-014-1550-0.

Trytek M, Fiedurek J, Gromada A (2016d) Effect of some abiotic stresses on the biotransformation of a-pinene by a psychrotrophic Chrysosporium pannorum. Biochem Eng J 112: 86-93. https://doi.org/10.1016/j.bej.2016.03.010.

Vespermann KA, Paulino BN, Barcelos MC, Pessôa MG, Pastore GM, Molina G (2017) Biotransformation of a-and $\beta$-pinene into flavor compounds. Appl Microbiol Biotechnol 101(5): 1805-1817. https://doi.org/10.1007/s00253-016-8066-7.

Vieira AJ, Beserra FP, Souza MC, Totti BM, Rozza AL (2018) Limonene: aroma of innovation in health and disease. Chem Biol Interact 283:97-106. https://doi.org/10.1016/j.cbi.2018.02.007.

Xu L, Møller KH, Crounse JD, Otkjær RV, Kjaergaard HG, Wennberg PO (2019) Unimolecular reactions of peroxy radicals formed in the oxidation of apinene and $\beta$-pinene by hydroxyl radicals. J Phys Chem A 123(8): 1661-1674. https://doi.org/10.1021/acs.jpca.8b11726.

Page 14/17 
Yue X, Ren R, Ma X, Fang Y, Zhang Z, Ju Y (2020) Dynamic changes in monoterpene accumulation and biosynthesis during grape ripening in three Vitis vinifera L. cultivars. Food Res Int 137: 109736. https://doi.org/10.1016/j.foodres.2020.109736.

Zhang LL, ZhangY, Ren JN, Liu YL, Li JJ, Tai YN, Shu-Zhen Y, Si-Yi P, Fan, G (2016) Proteins differentially expressed during limonene biotransformation by Penicillium digitatum DSM 62840 were examined using iTRAQ labeling coupled with 2D-LC-MS/MS. J Ind Microbiol Biotechnol 43(10): 1481-1495. https://doi.org/10.1007/s10295-016-1826-7.

\section{Figures}

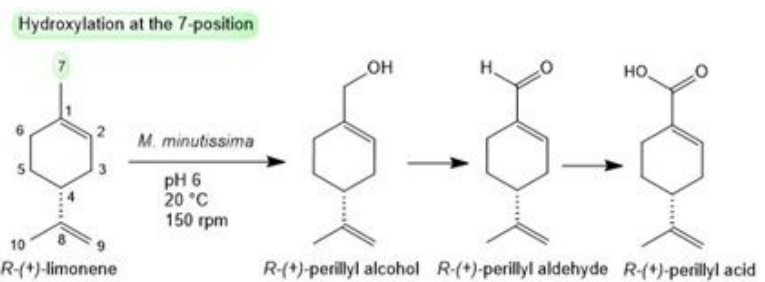

\section{Figure 1}

Proposed schematic of the biotransformation of R-(+)-limonene to perillic derivatives using M. minutíssima discussed in the work, reported by Trytek and Fiedurek 2005a.

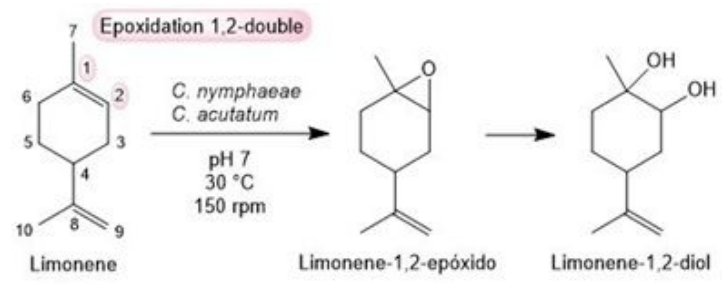

\section{Figure 2}

Proposed metabolic pathway of limonene to limonene-1,2-diol from biotransformation by Colletotrichum nymphaeae and Colletotrichum acutatum, as discussed in work of Sales et al. 2018b.

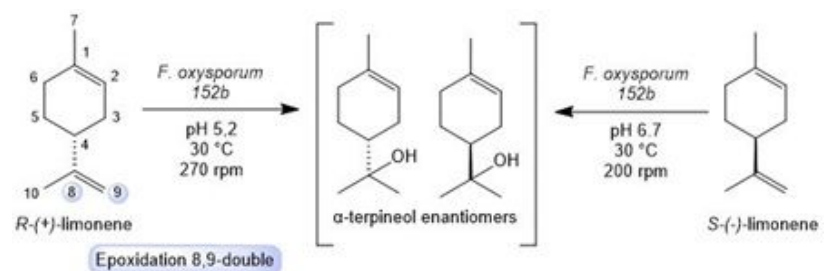

\section{Figure 3}

Proposed schematic of the epoxidation 8,9-double bond pathway by fungal-biotransformation of limonene enantiomers to a-terpineol enantiomers, as discussed in work of Bicas et al. 2008b and Bicas et al. 2010c. 


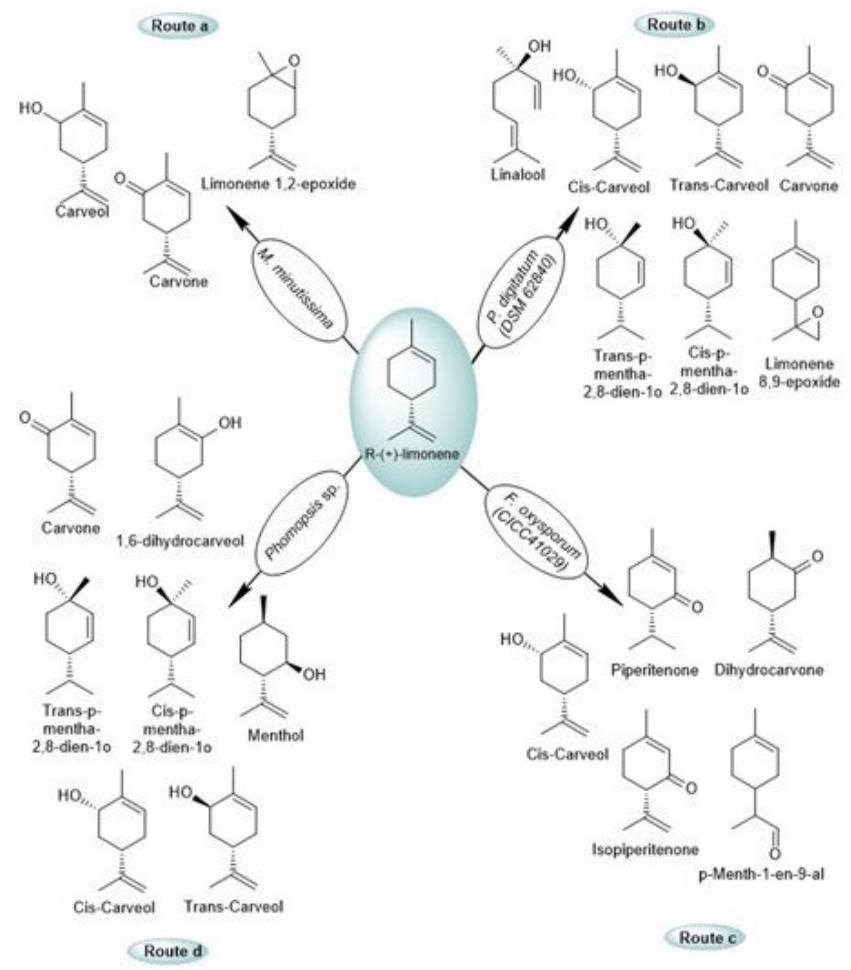

Figure 4

Proposed schematic of the main metabolic pathways of fungal biotransformation of R-(+)-limonene into many oxygenated derivatives, discussed in the work and reported by Route a - Trytek and Fiedurek 2005a; Route b - Prieto, Perea and Ortiz 2011; Route c - Tai et al. 2016; Route d - Bier, Medeiros and Soccol, 2017a.

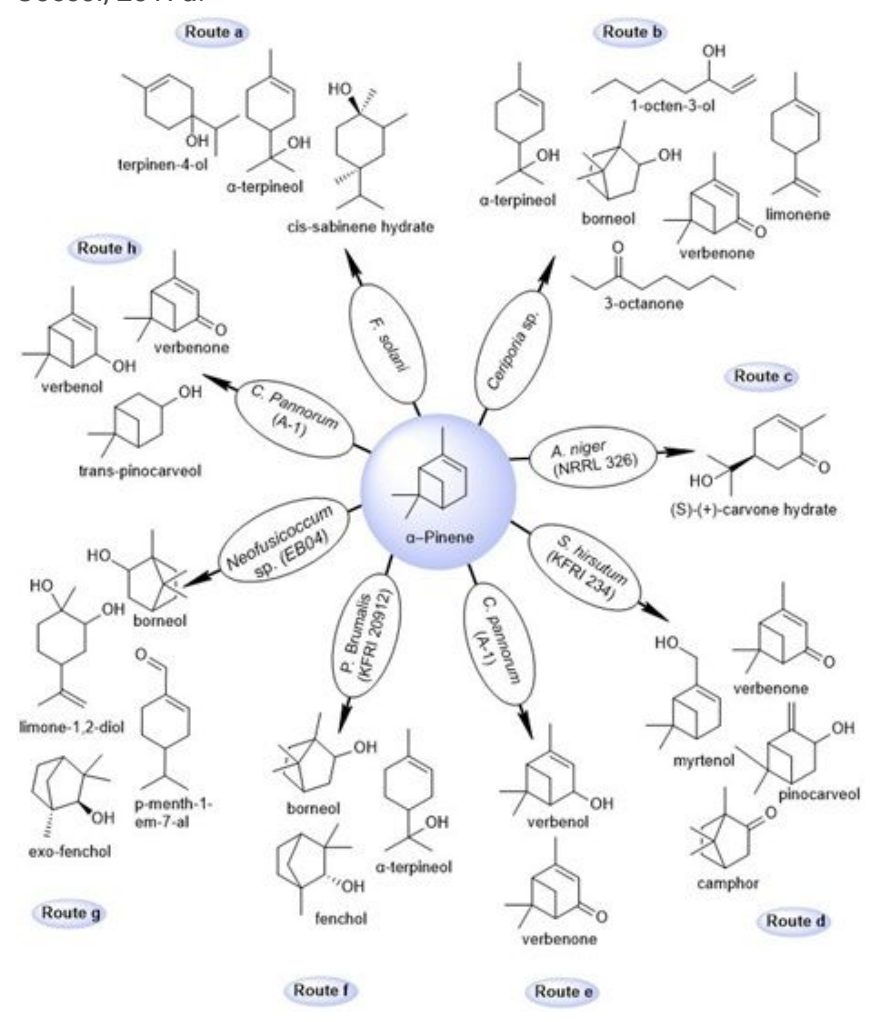

Figure 5

Proposed schematic of the of the fungal biotransformation of a-pinene into many oxygenated derivatives, discussed in the work and reported by Route a - Cecati et al. 2018; Route b - Lee et al. 2015a; Route c - Çorbacı 2020.; Route d - Lee et al. 2015a; Route e- Trytek, Jędrzejewski and Fiedurek 2015c; Route f - Lee et al. 2015b; Route g - Cecati et al. 2018; Route h - Trytek, Fiedurek and Gromada 2016d. 


\section{Supplementary Files}

This is a list of supplementary files associated with this preprint. Click to download.

- GraphicalAbstract.jpg 